\title{
PENGARUH BRAND FEELINGS TERHADAP LOYALITAS TAMU DI SHERATON SENGGIGI BEACH RESORT LOMBOK
}

\author{
Ihya Ulumuddin \\ Lili Adi Wibowo \\ Anthony Barbo \\ Manajemen Pemasaran Pariwisata FPIPS UPI
}

\begin{abstract}
Tourism is a service industry becomes global economic catalyst and a tool for socio-economic development. Tourism activities undertaken by tourists can not run if the lack of tourism products available to area attractions. The hotel is an integral part of the tourism business which is also a type of accommodation that uses some or all of the building to provide accommodation, food and beverage and other support services for the commercial general term. The level of competitionstar hotel development in Sindh particularly in the area of Senggigi Beach and grow up. Sheraton Senggigi Beach Resort Lombok. Occupancy rates are important to describe the extent to which the number of rooms at the hotel was sold. Sheraton Senggigi Beach Resort Lombok strive to maintain and enhance the guests to come and stay back there, and the guests who had been a guest can be spiritual so that advocates can recommend it to others. The higher the level of competition in the hospitality industry to make the management aware that the need to make a strategy to achieve the target of loyalty costumer. Which an effort to maintain and enhance guest loyalty is to approach a good and harmonious relationship with the guests through emotional approach and the feelings of the guests to the brand (Brand Feelings). The purpose of this research is to discover the feeling of a brand that made Sheraton Senggigi Beach Resort Lombok, guest loyalty at Sheraton Senggigi Beach Resort and determine the effect of brand loyalty feelings towards guests at the Sheraton Senggigi Beach Resort Lombok. Theory brand feeling using Kevin L. Keller, guest loyalty while using Griffin. Object of this study is the guests who stay at the Sheraton Senggigi Beach Resort.Type descriptive research and verification, and the method used is an explanatory survey sampling with stratified random sampling technique, we obtained a population of 100 respondents. Techniques of data analysis and hypothesis testing used is Analyisis path (path analysis is). The results showed that feelings brand consisting of warmth, fun, excitement, security, social approval, and self-respect gives a significant impact on guest loyalty. As for suggestions for companies to maintain and enhance guest loyalty at the Sheraton Senggigi Beach Resort is through the development of brand feelings are more interesting, creative, innovative, effective and efficient.
\end{abstract}

Keywords: Brand Feelings, Guest Loyalty, warmth, fun, excitement, security, social approval, selfrespect.

\section{PENDAHULUAN}

\subsection{Latar Belakang Penelitian}

Pariwisata merupakan industri jasa yang menjadi katalis ekonomi global dan salah satu alat untuk pembangunan sosial ekonomi di seluruh dunia. Menurut World Tourism Organization (UN-WTO) yang merupakan badan atau organisasi pariwisata dunia mengatakan bahwa satu dari delapan pekerja di dunia ini kehidupannya tergantung, langsung ataupun tidak langsung berhubungan dengan pariwisata.

Perkembangan pariwisata international saat ini mengalami peningkatan. Sepanjang tahun 2011 pariwisata dunia tumbuh 4,4 persen. Terkait dengan kondisi pariwisata dunia yang semakin membaik, Indonesia menjadikan hal itu sebuah peluang dalam meningkatkan pariwisata di Indonesia. Membaiknya kondisi pariwisata dunia tersebut menjadi salah satu pertimbangan Indonesia dalam meningkatkan target kunjungan wisatawan mancanegara (wisman) dari 6,54 juta pada tahun 2009, menjadi 7 juta pada tahun 2010. Wisatawan nusantara (wisnus) sendiri mengalami peningkatan setiap tahunnya. Pada tahun 2010 jumlah wisnus berjumlah 122.312.000 orang dengan total pengeluaran sebesar Rp. 150,49 triliun.

Kegiatan Pariwisata yang dilakukan oleh wisatawan tidak dapat berjalan jika tidak adanya produk pariwisata yang ada pada suatu daerah wisata. Hotel merupakan bagian integral dari usaha pariwisata yang juga merupakan jenis akomodasi yang 
menggunakan sebagian atau seluruh bangunan untuk menyediakan jasa penginapan, makanan dan minuman serta jasa penunjang lainnya bagi umum yang dikelola secara komersial. Selain hotel sebagai tempat menyediakan jasa penginapan, hotel juga saat ini merupakan salah satu tempat untuk menyediakan jasa kegiatan wisata MICE (Meeting, Incentive, Convention, Exhibition). Indonesia memiliki 10 destinasi MICE yang diunggulkan yaitu Jakarta, Yogyakarta, Surabaya, Bali, Medan, Bukit Tinggi-Padang, Makassar, Solo, Batam dan Manado. Sedangkan tiga daerah potensial yaitu Lombok-NTB, Balikpapan dan Bandung yang kemudian pada akhir tahun 2009 ditetapkan menjadi destinasi MICE yang diunggulkan.

Provinsi Nusa Tenggara Barat (NTB)Lombok saat ini termasuk salah satu daerah yang diunggulkan dalam potensi wisata MICE di Indonesia. Pemerintah mendukung wisata MICE demi suksesnya program Visit Lombok Sumbawa (VLS) tahun 2012 dengan target satu juta wisatawan. Berdasarkan laporan Dinas Pariwisata NTB, wisman pada triwulan I tahun 2011 sebesar 56.706 orang atau meningkat sekitar 4,52 persen dari triwulan I tahun 2010. Sementara jumlah wisnus pada triwulan I tahun 2011 sebesar 108.786 orang atau meningkat 22,63 persen dari triwulan I tahun 2010.

Provinsi NTB memiliki beberapa destinasi wisata dan salah satu destinasi wisata yang terkenal adalah Kawasan Wisata Pantai Senggigi yang terletak di Kabupaten Lombok Barat. Kawasan Wisata Pantai Senggigi sampai saat ini masih menjadi primadona bagi wisatawan dan menjadi icon bagi Kabupaten Lombok Barat maupun di Pulau Lombok. Lombok Barat memiliki berbagai wisata budaya dan heritage yang merupakan peniggalan kerajaan majapahit terdahulu. Salah satu destinasi yang cukup terkenal dengan wisata budaya dan heritage adalah Narmada.

Destinasi wisata di Lombok Barat yang saat ini masih menjadi primadona bagi wisatawan adalah Kawasan Pantai Senggigi. Banyaknya event-event nasional maupun international diadakan di kawasan tersebut, seperti pembukaan program VLS tahun 2012, pertemuan Menteri Luar Negeri antara negara-negara di Asia Tenggara, dan sebagainya. Sehingga potensi event MICE di Kawasan Pantai Senggigi semakin berkembang. Event-event MICE tersebut tidak lepas dari peranan penting hotel-hotel yang ada di Kawan Pantai Senggigi. Berdasarkan laporan dari Dinas Pariwisata Lombok Barat, saat ini banyaknya hotel di Kawasan Senggigi yaitu 51 hotel, dan 14 diantaranya adalah hotel berbintang.

Hotel Sheraton Senggigi Beach Resort Lombok merupakan hotel bintang lima yang ada di kawasan wisata Pantai Senggigi dan hotel chain international pertama di Pulau Lombok. Sheraton Senggigi Beach Resort menyadari bahwa persaingan dalam industri perhotelan semakin ketat. Persaingan dapat dilihat dari kemunculan hotel-hotel yang memberikan differentiation baik dari segi kualitas produk dan pelayanan maupun dari segi image perusahaan yang berbeda seperti Hotel The Santosa Lombok Resort yang melakukan re-branding dan membentuk positioning baru menjadi hotel bisnis sekaligus hotel berlibur bagi keluarga, serta merenovasi hotelnya dengan menambah jumlah kamar dan meeting room. Kemudian hotel Pool Villa Club dengan differentiation product yang memberikan pelayanan menginap hotel bintang lima terhadap tamunya dengan tema kamar yaitu villa. Secara tidak langsung hal ini akan membentuk citra baru terhadap hotel-hotel tersebut. Oleh karena itu Sheraton Senggigi Beach Resort dituntut untuk bersaing dengan hotel yang lainnya demi menjaga citra dan merek sebagai hotel chain international sesuai dengan filosofi perusahaannya.

Occupancy room Hotel Sheraton Sengigi Beach Resort mengalami fluktuasi. Tahun 2009 okupansi kamar Hotel Sheraton Senggigi Beach Resort Lombok sebesar 46,7\% dan pada tahun 2010 sebesar 60,2\%. Hal ini mengalami peningkatan sebesar 13,5\%. Namun untuk Repeated Guest mengalami penurunan dari tahun 2009 ke tahun 2010 sebesar $0,39 \%$. Terjadinya penurunan repeater guest pada tingkat hunian kamar mempengaruhi pula loyalitas tamu yang menginap. Karena repeater guest merupakan salah satu yang dapat menggambarkan loyalitas tamu menginap. Sheraton Senggigi Beach Resort telah mengikuti program dari Starwood Group, yaitu program Starwood Preffered Guest (SPG) member. SPG member merupakan program kesetiaan tamu yang ditujukan bagi para tamu menginap sebagai penghargaan terhadap tamunya.

Sheraton Senggigi Beach Resort telah melakukan survei mengenai loyalitas tamu Sheraton Senggigi Beach Resort, yang menyatakan bahwa tingkat loyalitas di 
Sheraton Senggigi Beach Resort Lombok mengalami penurunan pada Year To Date 2009 (YTD 09) sebesar 8,22\% menjadi $8,05 \%$ pada Year To Date 2010 (YTD 10). Menurunnya loyalitas tamu tersebut diakibatkan pula oleh menurunnya repeater guest walaupun tingkat hunian kamar mengalami kenaikan. Karena repeater guest dapat mempengaruhi loyalitas tamu.

Terjadinya loyalitas tamu menurun di Sheraton Senggigi Beach Resort, membuat pihak hotel menerapkan beberapa strategi pemasaran dalam meningkatkan loyalitas tamu. Serangkaian strategi yang dimiliki oleh Sheraton Senggigi Beach Resort saat ini sedang membangun "merek" (Sheraton) sebagai hotel yang bertujuan untuk memberikan (experience) pengalaman menginap sesuai core value yaitu warm, comforting, connecting, dan community. Terciptanya pengalaman yang sesuai dengan core value tersebut diimplementasikan melalui layanan khas yang dimiliki oleh perusahaan yang disebut dengan Sheraton Signature Service. Sheraton Signature Service ini merupakan pelayanan khas Sheraton yang membedakan dengan hotel lainnya. Pelayanan yang berbeda tersebut memberikan perasaan dan kesan terhadap nilai atau kekuatan merek yang berujung pada loyalitas tamu.

Sheraton Senggigi Beach Resort memiliki beberapa pelayanan yang melakukaan pendekatan terhadap tamu melalui panca inderanya, seperti menabuhkan salah satu alat musik tradisional indonesia yaitu "gong" sebagai tanda sambutan setiap tamu yang tiba atau datang ke hotel, kemudian di sekitar lobby hotel selalu diiringi musik tradisional khas Bali yaitu "Gamelan Bali" untuk menghangatkan suasana hotel, selain itu setiap ruangan diberikan wangian bunga lavender agar tamu merasa nyaman. Pendekatan secara emosional melalui panca indera tersebut memberikan perasaan hangat (warmth) dan betah setiap tamu yang menginap.

Loyalitas Tamu timbul dari adanya kepuasan tamu terhadap produk dan pelayanan hotel. Kepuasan pelayanan timbul ketika adanya hubungan yang baik antara tamu dengan perusahaan. Hubungan yang baik terjadi ketika adanya interaksi antara tamu dengan karyawan Sheraton Senggigi Beach Resort. Sheraton Senggigi Beach Resort memiliki 161 produk kamar dengan 7 jenis kamar sebagai core product dalam membangun kepuasan pada produk yang didukung dengan fasilitas-fasilitas hotel yang unik berstandar hotel bintang lima seperti Swimming Pool, Restaurant, Bar, Laguna Beach Spa, Ballroom, Drug Store, dan Health Club. Sheraton Senggigi Beach Resort memiliki staff yang memiliki standard operation, yakni setiap karyawan Sheraton Senggigi Beach Resort diwajibkan untuk bersikap ramah dan sopan sesuai dengan core value dalam memberikan pelayanan terhadap tamunya. Memberikan kepuasan produk dan pelayanan akan menciptakan perasaan senang (Fun) dan nyaman terhadap tamu.

Sheraton Senggigi Beach Resort menciptakan perasaan tertarik, menggairahkan dan menyenangkan (Excitement) terhadap tamu dengan menyediakan fasilitas yaitu konservasi penyu, dimana hal ini memberikan pengalaman menarik terhadap para tamu dengan memberikan kesempatan untuk melepaskan penyu ke pantai. Kemudian memberikan pengalaman menginap terhadap tamu dengan produk tempat tidur yang disebut dengan Sweet Sleeper Bed, dimana produk tempat tidur ini menggunakan sprai dan bantal yang terbuat dari bulu angsa yang sangat halus dan nyaman.

Setiap hotel dituntut untuk memberikan perasaan aman tarhadap tamunya. Begitu pula dengan Sheraton Senggigi Beach Resort yang memberikan rasa aman (security) dan privasi terhadap tamunya seperti menjaga identitas tamunya untuk tidak diketahui (unknown) oleh para tamu lainnya, tamu merasa bebas dalam melakukan apapun di hotel selama tidak mengganggu tamu lainnya. Kemudian fasilitas yang memberikan rasa aman yaitu seperti safety box di setiap kamar, pelayanan antar jemput bandara bagi tamu yang pertama kali datang ke Lombok, menyediakan penjaga keamanan pantai sekitar hotel, memiliki area private beach, peta area evakuasi bencana, fire alarm, dan lain-lain.

Sheraton Senggigi Beach Resort memberikan rasa percaya diri terhadap tamu dengan memberikan pelayanan terhadap tamu layaknya "raja" (self-respect) seperti program cocktail party bagi tamu yang long stay, dan memberikan kualitas pelayanan yang sesuai dengan standar bintang lima. Kemudian membentuk citra perusahaan sebagai hotel chain international dan hotel bintang lima pertama di Lombok, serta hotel 
bintang lima terfavorit tahun 2010 yang secara langsung berpengaruh terhadap peningkatan prestise dan rasa bangga bagi para tamu (social approval).

Semua hal yang diuraikan tersebut merupakan pelayanan khas (Sheraton Signature Service) yang dimiliki Sheraton Senggigi Beach Resort yang sangat berkaitan dengan indikator dan dimensi perasaan terhadap merek. Indikator tersebut mencakup semua perasaan terhadap merek yang warmth, fun, excitement, security, social approval, dan self-respect. Perasaanperasaan tersebut muncul ketika ataupun setelah tamu menginap (experience). Menurut modul Building World Class Brand (BWCB) Starwood Group (2011:6) menjelaskan bahwa merek merupakan perasaan yang muncul ketika menggunakan produk itu, pengalaman yang diberikan olehnya, serta kesetiaan tanpa penjelasan (loyalitas). Penelitian ini didukung oleh teori Keller (2008:68) dimana Brand Feelings merupakan salah satu enam building blocks dalam membangun ekuitas merek yang dapat mempengaruhi loyalitas tamu.

Berdasarkan latar belakang yang telah dikemukakan di atas maka perlu dikaji untuk suatu penelitian mengenai Brand Feelings yang dilakukan oleh Hotel Sheraton Senggigi Beach Resort dalam mempertahankan loyalitas tamu, sehingga penulis mengambil judul dalam skripsi ini yaitu: "Pengaruh Brand Feelings terhadap Loyalitas Tamu di Sheraton Senggigi Beach Resort" (Survei pada tamu menginap di Sheraton Senggigi Beach Resort Lombok).

\subsection{Rumusan Masalah}

Berdasarkan Latar Belakang di atas, maka dapat dirumuskan masalah penelitian sebagai berikut :

1. Bagaimanakah Brand Feelings yang dilakukan oleh Hotel Sheraton Senggigi Beach Resort.

2. Bagaimanakah loyalitas tamu menginap di Hotel Sheraton Senggigi Beach Resort.

3. Bagaimanakah pengaruh Brand Feelings (Warmth, Fun, Excitement, Security, Social Approval, dan Self-Respect) baik secara simultan maupun parsial terhadap loyalitas tamu menginap di Hotel Sheraton Senggigi Beach Resort.

\subsection{Tujuan Penelitian}

Berdasarkan rumusan masalah penelitian di atas maka tujuan penelitian ini adalah untuk memperoleh hasil temuan mengenai:

1. Brand Feelings yang dilakukan oleh Hotel Sheraton Senggigi Beach Resort.

2. Loyalitas Tamu menginap di Hotel Sheraton Senggigi Beach Resort.

3. Pengaruh Brand Feelings terhadap loyalitas tamu di Hotel Sheraton Senggigi Beach Resort.

\subsection{Kegunaan Penelitian}

Adapun kegunaan penelitian ini dapat dilihat dari kegunaan teoritis dan kegunaan praktis (empirik).

\subsubsection{Kegunaan Teoritis}

Hasil Penelitian ini diharapkan dapat memperluas kajian ilmu pengetahun manajemen pemasaran pariwisata, khususnya strategi Brand Feelings yang terdiri dari Warmth, Fun, Excitement, Security, Social Approval, dan Self-Respect terhadap loyalitas tamu di Hotel Sheraton Senggigi Beach Resort Lombok, serta dapat menjadi bahan acuan bagi penelitian selanjutnya dalam mengembangkan ilmu pemasaran pariwisata.

\subsubsection{Kegunaan Praktisi}

Secara praktisi, hasil penelitian ini diharapkan dapat memberikan masukanmasukan yang bermanfaat bagi pihak manajemen hotel yang ada di Kawasan Senggigi khususnya dalam mempertahankan loyalitas tamu melalui Brand Feelings yang terdiri dari Warmth, Fun, Excitement, Security, Social Approval, dan Self-Respect. Selain itu juga sebagai bahan evaluasi guna memodifikasi dan mengambil kebijakan atau langkah yang tepat dan sesuai berkaitan dengan keadaan atau permasalahan yang dihadapi oleh pihak manajemen hotel.

\section{KERANGKA PEMIKIRAN DAN} HIPOTESIS

\subsection{Kerangka Pemikiran}

Pemasaran merupakan kegiatan yang menghubungkan antara perusahaan dengan konsumen. Menurut Vankatesh dan Penaloza dalam Tjiptono (2008:4) mendefinisikan bahwa: "Pemasaran adalah serangkaian aktivitas yang dilakukan perusahaan untuk menstimulasi permintaan atas produk dan jasanya dan memastikan bahwa produk yang dijual dan disampaikan kepada para pelanggan". Sedangkan menurut Kotler dan Keller (2012:5) mengemukakan, pengertian pemasaran 
adalah sebuah proses kemasyarakatan di mana individu dan kelompok memperoleh apa yang mereka butuhkan dan inginkan dengan menciptakan, menawarkan, dan secara bebas mempertukarkan produk dan jasa yang bernilai dengan orang lain.

Pemasaran menyebabkan pelanggan siap membeli sehingga hanyalah bagaimana membuat produknya tersedia. Sedangkan proses pemasaran terdiri dari analisa peluang pasar, meneliti dan memilih pasar sasaran, merancang strategi pemasaran, merancang program pemasaran, dan mengorganisir, melaksanakan serta mengawasi usaha pemasaran. Untuk mencapai suatu pemasaran yang unggul, diperlukan strategi pemasaran.

Strategi pemasaran merupakan hal yang sangat penting bagi perusahaan dimana strategi pemasaran merupakan suatu cara mencapai tujuan dari sebuah perusahaan. Menurut Hermawan Kertajaya (2005:13) dalam suatu strategi pemasaran diperlukan suatu alat yang dipakai untuk memasarkannya yang disebut Strategic Place Triangle. Komponen inti dari Strategic Place Triangle tersebut yaitu: (1) Penetapan Positioning, Upaya untuk membangun suatu posisi dibenak pelanggan. (2) Pengembangan Differentiation, Upaya untuk membedakan diri melalui pemberian value proposition yang unik dan berbeda dari apa yang diberikan oleh daerah pesaing. (3) Membangun Brand. Membangun brand tidak lain adalah membangun awareness, asosiasi merek, persepsi kualitas, dan loyalitas merek.

Produk dan jasa digunakan sebagai salah satu strategi pemasaran dalam mengahadapi persaingan yang ketat, sebab didalamnya mengandung elemen merek yang kuat, sebagai suatu pembeda yang jelas, bernilai dan berkesinambungan penting. Menurut Kotler \& Keller (2012:258) mengungkapkan bahwa merek adalah "Produk atau jasa yang dimensinya mendifirensiasikan barang atau jasa tersebut dengan beberapa cara dari produk atau jasa lainnya yang dirancang untuk memuaskan kebutuhan yang sama". Di dalam perbedaan tersebut dapat bersifat rasional dan tangible maupun simbolik, emosional dan intangible. Dengan kata lain, merek mencerminkan keseluruhan persepsi dan perasaan konsumen mengenai atribut dan kinerja produk.

Menurut Kapferer (2008:9) "Brands are intangible assets, assets that produce added benefits for the business". Artinya bahwa merek adalah intangible assets, dimana assets yang menghasilkan keuntungan dan tambahan bagi bisnis atau perusahaan. Dengan kata lain bahwa merek memiliki nilai atau ekuitas merek bagi suatu perusahaan. Keller (2008:48) menyatakan bahwa ekuitas merek adalah efek diferensial pengetahuan merek atau tanggapan konsumen terhadap pemasaran merek.

Kotler dan Armstrong (2011:350) juga menambahkan bahwa brand equity adalah nilai dari suatu merek menurut sejauh mana merek itu mempunyai loyalitas merek (brand loyalty) yang tinggi, kesadaran merek (brand awareness), kualitas yang diterima (perceived quality), asosiasi merek yang kuat serta asset lain seperti paten, merek dagang, dan hubungan saluran. Sementara menurut Keller (2008:59), ada empat tahap untuk membangun ekuitas merek tersebut yaitu: (1) menyusun identitas merek yang tepat, (2) menciptakan makna merek yang tepat, (3) menstimulasi merek yang diharapkan, dan (4) menjalin relasi yang tepat dengan pelanggan. Di dalam proses implementasi dari empat tahap tersebut membutuhkan enam building blocks yaitu: (1) Brand Salience, (2) Brand Performance, (3) Brand Imagery (4) Brand Judgment, (5) Brand Feelings, (6) Brand Ressonance.

Penelitian ini menggunakan Brand Feelings dari Keller (2008:68) "Brand Feelings are customers emotional responses and reactions with respect to the brand". Artinya perasaan terhadap merek adalah tanggapan dan reaksi pelanggan yang secara emosi terhadap merek yang digunakan. Emosi yang ditimbulkan oleh merek ini, dapat menjadi begitu kuat, muncul ketika menggunakan atau mengkonsumsi merek. Tanggapan dan reaksi-reaksi pelanggan yang secara emosional berkenaan dengan merek, dapat muncul berupa:

1. Kehangatan (Warmth), Tipe perasaan meringankan, menimbulkan perasaan yang menyejukkan, kehangatan, tenang atau damai dan dari perasaan tersebut membuat konsumen menjadi sentimental dan ramah.

2. Menyenangkan (Fun), Tipe perasaan menghentak, menimbulkan perasaan yang membuat konsumen merasa terhibur atau kesenangan hati, keterangan hati, gembira, ceria, girang, riang, dan sebagainya.

3. Menggairahkan (Excitement), yang berarti indikator ini membuat 
konsumen merasakan semangat, berenergi dan mereka mendapatkan pengalaman sesuatu yang khusus dan spesial. Indikator ini menimbulkan excitement yang mungkin menghasilkan sebuah pengertian dari kegermbiraan.

4. Keamanan (Security), yang berarti indikator ini menghasilkan sebuah perasaan yang aman, kesenangan, dan perlindungan diri atau self-assurance. Sebagai akibat dari indikator ini, konsumen tidak perlu khawatir atau takut terhadap sesuatu yang akan menimpa diri mereka.

5. Persetujuan Sosial (Social approval), ketika menggunakan suatu merek akan menimbulkan perasaan positif bagi konsumen saat berhubungan dengan orang lain; konsumen merasa tampil lebih baik dengan penampilan mereka. Indikator munculnya pengakuan sosial ini ketika pelanggan merasa dengan menggunakan merek, dirinya lebih "bergaya," dan banyak orang menggunakan merek yang sama sehingga muncul komunitas pengguna merek; serta muncul kebanggan dalam menggunakan merek tersebut.

6. Penghargaan Diri (Self-respect), berarti ketika konsumen menggunakan suatu merek, maka akan menimbulkan perasaan lebih baik; konsumen merasa bangga, sukses, dan penuh percaya diri. Indikator munculnya manfaat selfrespect adalah ketika pengguna merek mendapatkan perasaan positif dan kehangatan disaat menggunakan merek; merek memberikan "arti” bagi konsumen; dan konsumen layaknya "raja" dalam menggunakan merek tersebut.

Hotel Sheraton Senggigi Beach Resort Lombok membangun Brand Feelings terhadap tamu yang menginap dengan mengimplementasikan keenam indikator pada brand feelings yaitu warmth, fun, excitement, security, sosial approval, dan self-respect. Hal ini untuk membangun merek yang akan meningkatkan kepuasan hingga mencapai loyalitas tamu yang menginap. Namun Sheraton Senggigi Beach Resort lebih memfokuskan dengan membangun hubungan perasaan dan emosional terhadap konsumen. Brand Feelings dapat mempengaruhi loyalitas pelanggan seperti yang dikemukakan oleh Passikoff (2006:92) dalam jurnal Predicting
Market Sucsess yang mengandung makna bahwa menciptakan loyalitas diri sebagai pelanggan berbasis emosi dapat dilakukan berdasarkan langkah-langkah khusus salah satunya adalah perasaan tentang kategori atau merek (brand feelings).

Pada dasarnya loyalitas tamu didefinisikan sebagai sebuah kesetiaan seseorang terhadap suatu hal. Menurut Ajzen dalam Ali Hasan (2008:86) bahwa Loyalitas merupakan kondisi psikologis (attitudinal dan behavioral) yang berkaitan dengan sikap terhadap produk, konsumen akan membentuk keyakinan menetapkan suka dan tidak suka, dan memutuskan apakah mereka ingin membeli produk. Sedangkan menurut Griffin (2005:4) bahwa, konsep loyalitas lebih mengarah kepada perilaku (behavior) dibandingkan dengan sikap (attitude) dan seorang pelanggan yang loyal karena memperlihatkan perilaku pembelian yang dapat diartikan sebagai pola pembelian yang teratur dan dalam waktu yang lama, yang dilaukuan oleh unit-unit pembuat atau pengambil keputusan.

Zeithaml dan Biner dalam Vanessa (2007:74) menyatakan bahwa karekteristik loyalitas tamu yang didasarkan pada dimensi perilaku dan sikap adalah merekomendasikan hal-hal positif untuk perusahaan kepada orang lain, melakukan bisnis lebih banyak dengan perusahaan di masa yang akan datang, mempertimbangkan perusahaan sebagai pilihan pertama dimasa yang akan datang.

Sedangkan menurut Griffin (2005:31), pelanggan yang loyal memiliki karakteristik yaitu melakukan pembelian secara teratur (makes regular repeat purchases), membeli diluar lini produk tau jasa (purchases across product and service lines), merekomendasikan kepada orang lain (refers other), menunjukan kekebalan dari daya tarik produk sejenis dari pesaing (demonstrantes immunity to the full of the competition).

Loyalitas tamu adalah salah satu tujuan akhir dari sebuah hotel karena tamu yang loyal dapat menjamin kelangsungan hidup hotel dalam jangka panjang. Selain itu karakteristik dari tamu yang loyal ialah seseorang yang kebal terhadap daya tarik hotel lain dan selalu memberikan masukan bagi hotel yang bersangkutan. Tamu yang loyal akan turut mempromosikan hotel melalui word of mouth yang kuat, merekomendasikan kepada orang lain. Salah satu langkah untuk meningkatkan loyalitas 
tamu adalah membangun merek dengan memberikan perasaan positif terhadap merek melalui produk dan jasa yang ditawarkan kepada tamu.

\subsection{Hipotesis}

Sugiono (2010:93), mengemukakan hipotesis sebagai "Suatu jawaban yang bersifat sementara terhadap permasalahan penelitian sampai terbukti melalui data yang terkumpul."

Berdasarkan teori-teori yang telah dikemukakan maka diajukan hipotesis yang akan dibuktikan melalui penelitian. Hipotesis merupakan jawaban sementara terhadap masalah penelititan yang dibangun berdasarkan kerangka teoritis tertentu yang kebenarannya perlu diuji secara empiris. Hipotesis merupakan jawaban sementara terhadap rumusan masalah penelitian (Sugiono, 2010:51).

Penelitian dalam menyusun hipotesis didukung oleh premis sebagai berikut:

1. Robert Passikoff (2006:92) mengemukakan bahwa: Making the magic of human emotion the foundation of brand marketing and all that goes into it. Follow this process and you will find yourself viewing loyalty as an emotions-based customer hologram, a virtual tap into the future behavior of your target audiences based on specific measures such as: Feelings about the category or brand.

2. Arthur, Patricia, Whipple, dan Ellinger (2011:190-204) dalam Journal of Product \& Brand Management: "A large proportion of consumers clearly have strong feelings about the supermarket (brands) they patronize (loyalty)".

Berdasarkan premis-premis tersebut peneliti mengemukakan hipotesis, maka hipotesis dalam penelitian ini adalah:

Adanya pengaruh positif dan signifikan baik secara parsial maupun simultan antara pengaruh brand feelings terhadap loyalitas tamu. (didukung oleh premis dari 1, 2).

\section{METODE PENELITIAN}

\subsection{Objek Penelitian}

Objek dari penelitian ini adalah tamu yang menginap di Hotel Sheraton Senggigi Beach Resort Lombok. Berdasarkan dengan objek penelitian tersebut, maka yang dianalisa mengenai Pengaruh Brand Feelings terhadap Loyalitas Tamu Menginap di Hotel Sheraton Senggigi Beach Resort Lombok.

Menurut Sugiyono (2010:59), variabel independent atau variabel bebas adalah variabel yang mempengaruhi atau yang menjadi sebab berubahnya atau timbulnya variabel dependent (terikat). Variabel independent (bebas) adalah Brand Feelings (X) yang memiliki enam indikator yaitu warmth, fun, excitement, security, social approval, dan self-respect. Menurut Pabundu Tika (2006:19) Variabel terikat (dependent) adalah suatu variable yang dipengaruhi oleh variable bebas. Sedangkan menurut Uma Sekaran (2008:116), variabel terikat merupakan variabel utama yang menjadi faktor yang berlaku dalam investigasi, analisisi ini untuk menemukan jawaban atau solusi atau masalah. Variabel dependent (terikat) yaitu Loyalitas Tamu yang terdiri dari Behavioral dan Attitude.

\subsection{Metode Penelitian.}

Penelitian ini menggunakan dua jenis penelitian yaitu deskriptif dan verifikatif. Menurut Traver Travens dalam Husein Umar (2008:21) bahwa "Penelitian dengan menggunakan metode deskriptif adalah penelitian yang dilakukan untuk mengetahui nilai variabel mandiri baik satu variabel atau lebih (independent) tanpa membuat perbandingan atau menghubungkan dengan variabel lain". Hal ini serupa dengan yang dikemukakan oleh Donald R. Cooper dan Pamela S. Schindler (2008:159) menjelaskan "Jika suatu riset berkaitan dengan menemukan siapa, apa, dimana, kapan dan berapa banyak, maka studinya adalah deskriptif"

Di dalam penelitian yang menggunakan penelitian deskriptif ini bertujuan untuk memperoleh gambaran mengenai Brand Feelings dan gambaran mengenai loyalitas tamu pada sebuah hotel. Penelitian ini menggunakan model piramida mengenai loyalitas yang dikemukakan oleh Ajzen dalam Ali Hasan (2008:86) dan Griffin (2005:4) dengan memodifikasi teori yang dikemukakan oleh Zikmund.

Pada dasarnya, dalam penelitian verifikatif ingin menguji kebenaran dari suatu hipotesis yang dilakukan melalui pengumpulan data dilapangan. Melalui penelitian verifikatif ini data-data dikumpulkan dari sumber data primer dan sekunder. Data primer diperoleh dengan menyebar kuesioner kepada sampel responden untuk memperoleh fakta yang 
relevan. Dalam penelitian ini di uji mengenai pengaruh Brand Feelings terhadap loyalitas tamu Hotel Sheraton Senggigi Beach Resort Lombok.

Setiap penelitian diperlukan suatu metode untuk mempermudah penulis dalam membuat suatu kesimpulan. Berdasarkan jenis penelitian ini yang digunakan yaitu deskriptif dan verifikatif dengan melakukan pengumpulan data di lapangan, maka metode penelitian yang digunakan adalah metode deskriptif survey dan metode explanatory survey. Dalam penelitian ini akan menggunakan metode cross section method, yaitu "Metode yang dilakukan hanya sekali dan mewakili satu periode tertentu dalam waktu" (Donald R. Cooper dan Pamela S. Schindler, 2008:160).

Maksud dari metode survei menurut Kerlinger, yang dikutip oleh Sugiyono (2010:7), yaitu:

Metode penelitian yang dilakukan pada populasi besar maupun kecil tapi data yang dipelajari adalah data dari sampel yang diambil dari populasi tersebut, sehingga ditemukan kejadian-kejadian relatif. Distribusi dan hubungan-hubungan antar variabel sosiologis maupun psikologis.

Menurut Sugiyono (2010:7) metode explanatory survey adalah metode penelitian yang dilakukan pada populasi besar maupun kecil, tetapi data yang dipelajari adalah data dari sampel yang diambil dari populasi tersebut. Sehingga ditemukan kejadiankejadian relatif, distribusi dan hubunganhubungan antar variabel sosiologis maupun psikologis.

\section{HASIL PENELITIAN DAN PEMBAHASAN \\ 4.1 Rekapitulasi Hasil Tanggapan Tamu Sheraton Senggigi Beach Resort Terhadap Brand Feelings.

\begin{tabular}{|c|c|c|c|c|}
\hline No & Sub Variabel & Total Skor & $\begin{array}{c}\text { Skor } \\
\text { Rata- } \\
\text { rata }\end{array}$ & $\%$ \\
\hline 1 & Warmth & 1598 & 4,00 & 14,02 \\
\hline 2 & Fun & 2945 & 4,21 & 25,84 \\
\hline 3 & Excitement & 1864 & 4,66 & 16,36 \\
\hline 4 & Security & 2226 & 4,45 & 19,53 \\
\hline 5 & $\begin{array}{c}\text { Social } \\
\text { Approval }\end{array}$ & 1663 & 4,16 & 14,59 \\
\hline 6 & Self-Respect & 1101 & 3,67 & 9,66 \\
\hline & Total & 11397 & 25,15 & 100,00 \\
\hline
\end{tabular}

Sumber : Hasil Pengolahan Data 2011

Berdasarkan Tabel 4.16 dapat terlihat bahwa sub variabel dari brand feelings di Sheraton Senggigi Beach Resort Lombok yang mendapatkan penilaian tertinggi yaitu pada Fun sebesar 25,84\%. Hal ini dikarenakan Sheraton Senggigi Beach Resort Lombok selalu berusaha memberikan nilai fasilitas dan pelayanan yang terbaik mulai dari kemudahan mengakses internet, perasaan dengan kelengkapan fasilitas channel TV kabel, kinerja karyawan front office dalam melayanai proses check in atau check out, fasilitas pendukung hotel, fasilitas room service, tingkat harga dengan kualitas yang diberikan, dan intensitas discount yang diberikan agar tamu selalu merasa senang dan puas ketika menginap di Sheraton Senggigi Beach Resort Lombok.

Sedangkan sub variabel yang mendapatkan penilaian terendah yaitu Selfrespect sebesar 9,66\%. Hal ini disebabkan karena masih terdapat kekurangan dalam memberikan perasaan positif terhadap tamu yang menginap yaitu beberapa karyawan yang kurang tanggap, cepat dan tidak sesuai dengan harapan tamu ketika memberikan service room.

\subsection{Rekapitulasi Hasil Tanggapan Loyalitas Tamu Sheraton Senggigi Beach Resort}

\begin{tabular}{|c|l|c|c|c|}
\hline No & Sub Variabel & $\begin{array}{c}\text { Total } \\
\text { Skor }\end{array}$ & $\begin{array}{c}\text { Skor } \\
\text { Rata- } \\
\text { rata }\end{array}$ & $\%$ \\
\hline 1 & Attitude & 1441 & 3,60 & 37,51 \\
\hline 2 & Behaviour & 2401 & 3,43 & 62,49 \\
\hline \multicolumn{2}{|c|}{ Total } & 3842 & 10,03 & $100 \%$ \\
\hline
\end{tabular}

Sumber: Hasil pengolahan data 2012.

Berdasarkan Tabel 4.19 dapat terlihat bahwa dari pelaksanaan loyalitas tamu Sheraton Senggigi Beach Resort Lombok yang mendapatkan penilaian tertinggi yaitu pada behaviour tamu Sheraton Senggigi Beach Resort Lombok sebesar 62,49\%, hal ini dikarenakan Sheraton Senggigi Beach Resort Lombok dalam menjalankan program di hotel selalu berusaha untuk memberikan pelayanan dengan menyentuh perasaan tamu yang menginap di hotel serta kelengkapan fasilitas di hotel yang semakin beragam. Dengan demikian frekuensi tamu menginap akan meningkat apabila setiap tamu menyukai setiap pelayanan dan fasilitas yang ada di Sheraton Senggigi Beach Resort Lombok.

Sedangkan sub variabel yang terendah yaitu attitudes tamu sebesar $37,51 \%$, hal ini disebabkan mayoritas tamu yang menginap biasanya mereka menginap di hotel karena ada kerjasama dengan perusahaan, adanya penawaran khusus, diskon dan lain 
sebagainya, sehingga tingkatan loyalitasnya pun belum cukup tinggi. Hal ini mengakibatkan sikap dari tamu terhadap loyalitas pada Sheraton Senggigi Beach Resort Lombok masih kecil.

Berdasarkan hasil pengolahan yang telah disajikan diatas, dapat dilihat bahwa skor total untuk loyalitas tamu Sheraton Senggigi Beach Resort Lombok adalah 3.842 .

\section{KESIMPULAN}

\subsection{Kesimpulan.}

Berdasarkan hasil penelitian yang telah dilakukan dengan menggunakan analisis deskriptif dan verivikatif dengan menggunakan path analysis, antara brand feelings terhadap loyalitas tamu Sheraton Senggigi Beach Resort Lombok, maka berdasarkan penelitian tersebut dapat diambil kesimpulan sebagai berikut:

1. Secara keseluruhan brand feelings pada Sheraton Senggigi Beach Resort Lombok sudah baik, terutama fun, dikarenakan para tamu merasa senang dan puas ketika menggunakan fasilitas pendukung dan pelayanan yang telah ditawarkan oleh Sheraton Senggigi Beach Resort Lombok, sehingga mempengaruhi para tamu untuk terus menerus menggunakan kembali fasilitas dan pelayanan yang diberikan Sheraton Senggigi Beach Resort Lombok.

2. Self-respect mendapatkan penilaian terendah. Walaupun secara signifikan berpengaruh terhadap loyalitas tamu pada Sheraton Senggigi Beach Resort Lombok, namun dirasa masih kurang dampaknya. Dimana tamu belum merasakan perasaan senang (fun) dalam pemberian jasa Sheraton Senggigi Beach Resort Lombok, terutama dalam memberikan fasilitas dan pelayanan mewah yang sesuai dengan standarisasi hotel bintang lima sehingga membuat tamu yang menginap merasa layaknya seorang "raja".

3. Gambaran mengenai penciptaan loyalitas tamu Sheraton Senggigi Beach Resort Lombok yang terdiri dari attitude dan behavior. Behavior mendapatkan penilaian yang paling tinggi hal ini dikarenakan Sheraton Senggigi Beach Resort Lombok selalu berusaha untuk memberikan pelayanan-pelayanan yang menyentuh perasaan positif setiap tamu yang menginap di hotel serta kelengkapan fasilitas di hotel yang semakin beragam. Dengan demikian frekuensi tamu menginap akan meningkat apabila tamu menyukai pelayanan yang menyentuh perasaannya secara positif oleh Sheraton Senggigi Beach Resort Lombok.

4. Brand Feelings Sheraton Senggigi Beach Resort Lombok yang terdiri dari Warmth, Fun, Excitement, Social Approval, dan Self-respect memberikan pengaruh terhadap loyalitas tamu di Sheraston Senggigi Beach Resort Lombok dengan tingkat pengaruh yang tinggi.

\section{a. Rekomendasi}

Konsep brand feelings merupakan hal yang penting dalam suatu perusahaan, karena memiliki beberapa keuntungan diantaranya adalah mengurangi biaya pemasaran, memudahkan akses, menarik pelanggan baru, mempertahankan pelanggan, ekuitas merek, dan banyak lagi keuntungan yang bias diperoleh melalui brand feelings, dalam hal ini penulis mencoba memberikan saran seperti hal-hal berikut:

1. Secara keseluruhan Brand Feelings di Sheraton Senggigi Beach Resort Lombok yang terdiri dari Warmth, Fun, Excitement, Social Approval, dan Selfrespect sudah dilakukan dengan baik dan terbukti mampu mempengaruhi loyalitas tamu di Sheraton Senggigi Beach Resort, namun hal terpenting yang harus diperhatikan oleh pihak manajemen Sheraton Senggigi Beach Resort Lombok adalah mengenai fasilitas pendukung dan kualitas pelayanan yang sesuai dengan standar kemewahan hotel bintang lima. Meningkatkan kinerja karyawan dalam memberikan pelayanan yang ramah dengan pendekatan secara personal terhadap tamu yang menginap agar tamu merasa layaknya seorang "raja", sehingga tamu bisa memberikan kepercayaan yang lebih kepada perusahaan dan memiliki keterikatan perasaan yang kuat serta menggunakan fasilitas dan pelayanan hotel secara terus menerus. Hal tersebut sejalan dengan perolehan nilai yang terendah pada dimensi self-respect.

2. Loyalitas Tamu secara umum dapat dinilai cukup baik, dan Fun (menyenangkan) mempunyai pengaruh positif terhadap penciptaan loyalitas 
tamu Sheraton Senggigi Beach Resort Lombok oleh karena itu secara keseluruhan hotel harus dapat meningkatkan fasilitas pendukung dan kualitas pelayanan yang dapat memberikan perasaan senang (fun) dan puas terhadap tamu yang menginap, meningkatkan frekuensi menginap tamu dan tentunya meningkatkan penciptaan loyalitas tamu yang menginap di Sheraton Senggigi Beach Resort Lombok. Hotel dapat pula melakukan riset mengenai sejauh mana tingkat penciptaan loyalitas tamu Sheraton Senggigi Beach Resort melalui Brand Feelings, sehingga hasilnya dapat dijadikan bahan pertimbangan dalam merancang strategi pemasaran.

3. Kekurangan dari penelitian ini yaitu penelitian hanya dilakukan kepada tamu yang menginap di Sheraton Senggigi Beach Resort Lombok, dan terdapat faktor lainnya yang mempengaruhi loyalitas diluar program ini. Untuk peneliti selanjutnya disarankan untuk dapat meneliti factor-faktor lainnya yang mempengaruhi loyalitas selain Brand Feelings. Khususnya untuk tamu corporate atau instansi-instansi pemerintah, karena Sheraton Senggigi Beach Resort Lombok telah banyak menjalin kerjasama dengan perusahaan khususnya mengenai corporate rate, sehingga tingkat hunian dari tamu corporate juga tinggi.

\section{DAFTAR PUSTAKA}

\section{DAFTAR PUSTAKA}

Aaker, A. David. 2009. Manajemen Ekuitas Merek. Ahli bahasa oleh Aris Ananda, Jakarta: Mitra Utama.

Assael, H., 2001. Consumer Behavior and Marketing Action, New York University: South Western College Publishing

Ahuvia, Aaron, Rajeev Batrav, Richard Bagozzi. 2008. Brand Love:" Towards an Integrative Model". Consumer Research Vol.35

Assauri, Sofyan. 2007. Manajemen Pemasaran Modern : Dasar, Konsep, dan Strategi. Jakarta: Penerbit PT. Raja Grafindo Persada

Buchari Alma. 2007. Manajemen Pemasaran dan Pemasaran Jasa. Bandung : CV Alfabeta.

Brunner, T.A, Stocklin M., Opwis K.,. 2010. Satisfaction, image and loyalty: new versus experienced customers, European Journal of Marketing, Vol 42, No 9/10.

Carrol, B.A and A.C, Ahuvia. 2006. Some Antecedents and Outcomes of Brands Love, Marketing Letters, Vol.17, No.12, pp.79-89.

Erna, Ferrinadewi, 2005, “Pengaruh Tipe Keterlibatan Konsumen terhadap Kepercayaan Merek dan Dampaknya pada Keputusan Pembelian", Modus Vol. 17

Fandy Tjiptono. 2005. Brand Management \& Strategy. Yogyakarta: Andi.

Pemasaran Jasa. Solo: Andi

2008.

Pemasaran Strategik. Yogyakarta: Penerbit Andi.

Gobe, Marc. 2009. Emotional Branding: The New Paradigm for Connecting Brands to People. New York: Sky Hourse Inc.

Griffin, Jill. 2005. Customer Loyalty: Edisi Revisi dan Terbaru. Jakarta: Erlangga

Hasan, Ali. 2008. Marketing. Yogyakarta: MedPress

Hermawan Kertajaya. 2009. In Marketing. Bandung: Mizan Pustaka

Attracting Tourists Traders

Investors. Jakarta: PT Gramedia Pustaka Utama.

Hermawan, Asep. 2008. Penelitian Bisnis Paradigma Kuantitatif. Jakarta: PT. Grasindo.

Husein, Umar. 2008. Metode Penelitian untuk Skripsi dan Tesis Bisnis. Jakarta: Rajagrafindo Persada.

Hurriyati, Ratih. 2010. Bauran Pemasaran dan Loyalitas Konsumen. Bandung: Alfabeta

Jean-Jacques Lambin, 2007, "Measuring The Affective Response" Market Driven Management Supplementary web resource material, Palgrave Macmillan.

Kapferer, Jean-Noël. 2008. New Strategic Brand Management : Creating And Sustaining Brand Equity Long Term $4^{\text {th }}$ Edition. London and Philadelphia: Kogan Page Limited.

Kotler, Philip. $2009 . \quad$ Marketing Management: Analysis, Planning, Implementation and Control, Millenium Edition. New Jersey: Printice Hall. 
Kotler, Philip., John T., Bowen, \& James C. Makens. Marketing for Hospitality and Tourism $4^{\text {th }}$ Edition. New Jersey: Prentice Hall.

---- \& Gary, Amstrong. 2011. Principles of Marketing. New Jersey: Prentice Hall. 2012. Marketing Management. New Jersey: Prentice Hall.

Keller, Kevin Lane. 2008. Strategic Brand Management: Building, Measuring, and Managing Brand Equity, $3^{\text {nd }}$ Edition, New Jersey: Prentice Hall

Noor Suroija 2010. Studi Tentang Brand Resonance Melalui Brand Feelings Pada Honda Tiger di Kota Semarang. Semarang: UNDIP

Olsen, O. Svein. 2002. Journal of The Academy of Marketing Science: Comparative evaluation and the relationship between quality, satisfaction, and repurchase loyalty. Vol. 30, No. 3, pp. 240249.

Pabundu, Tika. 2006. Metodologi Riset Bisnis. Jakarta: PT. Bumi Aksara

Passikof, Robert. 2006. Predicting Market Success: New Ways to Measure Cutomer Loyalty and Engage Consumers with Your Brand. New Jersey: John Wiley \& Sons Inc.

Stanton, William. Y. (2005). Fundamental of marketing. New York: McGrawHill, Inc.

Starwood, Group. 2010. Modul "Building World Class Brand". Nusa Tenggara Barat: Sheraton Senggigi Beach Resort.

Strydom, Lelani. 2004. Internal Marketing In A Service Organization. Rand Afrikaans University.

Silalahi, Ulber. 2009. Metode Penelitian Sosial, Bandung: PT Refika Aditama

Sekaran, Uma, (2008). Metodologi Penelitian Untuk Bisnis, Jakarta: Salemba Empat.

Sugiono. 2010. Metode Penelitian Bisnis. Bandung : Alfabeta.

Suharsimi, Arikunto. 2006. Prosedur Penelitian Pendidikan. Jakarta: Rineka Cipta.

Penelitian Bisnis. Bandung: Alfabeta.
Sunarto. 2006. Manajemen Sumber Daya Manusia (MSDM) Strategik. Yogyakarta: AMUS

Wibowo, Lili Adi. 2008. Experiental Marketing Pengaruhnya Terhadap Branded Costumer Experience dan Loyalitas Pelanggan Restoran dan Café Serta Dampaknya Pada Citra Bandung Sebagai Destinasi Pariwisata Indonesia. Jurnal Penelitian Desertasi Dosen Universitas Pendidikan Indonesia

Vanessa, Gaffar. 2007. CRM dan MPR Hotel. Bandung: Alfabeta

Zikmund, William G, Raymond McLeod, Jr, \& Faye W. Gilbert, 2003, Customer Relationship Management: Integrating Marketing Strategy and Information Technology. John Willey\&Sons, Ltd: USA.

UN-WTO World Tourism Barometer. Volume 7 No.4 Agustus 2010. Akses pada tanggal 21 Oktober 2009. http://www.unwto.org/facts/eng/bar ometer.html

UN-WTO World Tourism Barometer. Akses tanggal 16 Juni 2010. http://kolom.pacific.net.id

Statistik Kepariwisataan Indonesia. Akses 16 Juni 2010. http://www.bpr.go.id/ www.AntaraMataram.com www.indonesia.travel http://travel.kompas.com/read : Kamis, 12 Januari 2012 / 11.05 WIB

http://analisis.vivanews.com/news/read/2802 03-pariwisata-ri-butuhinfrastruktur : Senin, 16 Januari 2012 / 06:22 WIB

http://lib.atmajaya.ac.id/default.aspx?tabID $=61 \& s r c=k \& i d=158523$

http://eprints.upnjatim.ac.id/824/1/File_1.pd 
